\title{
What Determines Annuity Demand at Retirement?
}

\author{
Giuseppe Cappelletti, Giovanni Guazzarotti and Pietro Tommasino \\ Research Department, Bank of Italy, Via Nazionale, 91, Rome 00184, Italy. \\ E-mails: giuseppe.cappelletti@bancaditalia.it; giovanni.guazzarotti@bancaditalia.it
}

We study the determinants of the demand for annuities using survey data from Italy. Eliciting potential demand with an ad hoc question, we are able, contrary to most previous studies, to disentangle demand from supply-side effects. Our results highlight the do importance of wealth, impatience, education and financial literacy in shaping annuity demand. In particular, not only do poor people annuitise less; they are also characterised by a higher elasticity of annuity demand to prices. This result suggests that prices higher than those actuarially fair should concern policymakers and regulators not only on efficiency, but also on fairness grounds.

The Geneva Papers (2013) 38, 777-802. doi:10.1057/gpp.2012.43

Keywords: annuities; retirement; italian pension system; financial literacy

Article submitted 7 October 2011; accepted 31 July 2012; published online 24 October 2012

\section{Introduction}

An annuity is an insurance contract in which, in exchange for an up-front premium, the insurer promises a stream of payments to the purchaser, the annuitant, until the insured person dies. Accordingly, annuitants are able to transform pension wealth at retirement into a regular life-long stream of benefits.

It is a well-established fact in economic theory that risk-averse individuals should annuitise a significant part of their wealth. ${ }^{1}$ The intuition behind this result is straightforward. ${ }^{2}$ Consider a worker on the verge of retirement who has to choose the level of consumption for the coming years, given their level of wealth. Without annuities, workers would be exposed to both sides of longevity risk: if they live longer than expected, they could outlive their resources; if on the contrary their lifespan turns out to be shorter than expected, some resources are wasted. By buying an annuity, longevity risk is shifted onto the insurance company. As companies have a wide pool of clients, they can diversify the idiosyncratic component of the longevity risk, ${ }^{3}$ so they can offer, in principle, annuities at a reasonable price for the individual client. ${ }^{4}$

\footnotetext{
${ }^{1}$ Yaari (1965). More recently, see Davidoff et al. (2005) and Sheshinski (2007).

${ }^{2}$ Modigliani (1986).

${ }^{3}$ They only have to bear the aggregate component, that is, the risk of unpredicted changes in the average lifespan (Visco, 2007).

${ }^{4}$ This is true if we abstract from asymmetric information (which creates adverse selection problems) and administrative costs, which are of course very important real-world phenomena. A thorough and up-to-date theoretical treatment of these aspects can be found in Sheshinski, op. cit. References to the empirical research can be found below (footnote 57).
} 
As it is well known, social security wealth, which typically constitutes the biggest share of a retiree's wealth, comes in an annuitised form. However, in most advanced countries, future retirees will have to rely less on social security schemes and more on funded pension plans, ${ }^{5}$ which mostly leave the worker to choose between cashing out and annuitising pension wealth at retirement. Within employer-sponsored pension plans, the shift from defined benefit (DB) schemes (which mostly require annuitisation at retirement) to defined contribution (DC) schemes (which often do not even have annuitisation as an option) raises similar concerns. Therefore, a better understanding of the demand for annuities will soon become a priority for policymakers and regulators.

In this paper, we propose a way to estimate the annuity demand schedule. We use data from the Survey of Household Income and Wealth (SHIW), a large representative survey of the Italian population conducted by the Bank of Italy every two years. In the 2008 wave, all heads of household were asked the following question: ${ }^{6}$

Imagine you are 65 years old and receive a total pension income of 1,000 euros a month (adjusted for inflation). Would you be willing to give up half that pension for the whole of your old age in exchange for a lump sum of 60,000 euros to be paid immediately? ${ }^{7}$

Respondents who preferred the annuity to the lump sum were then asked the same question with the lump sum increased to $€ 80,000$; those who still preferred the annuity to the $€ 80,000$ lump sum were asked the same question again with the lump sum increased to $€ 100,000$. The $€ 80,000$ payment corresponds to the price that would leave a risk-neutral 65-year-old married male indifferent, in net present value terms, between buying and not buying the annuity, considering the most up-to-date official mortality rates ${ }^{8}$ and a 3 per cent real interest rate (which is the one imposed by the national regulators to all the annuity sellers ${ }^{9}$ ). The answers to this battery of questions represent our dependent variable.

To date, it has proved very difficult to assess annuity demand and its determinants empirically, ${ }^{10}$ mainly due to the fact that annuity markets are very thin (in most countries individual demand is basically non-existent). ${ }^{11}$ Brown $^{12}$ considers a

${ }^{5}$ Feldstein and Siebert (2002); Diamond and Orszag (2004).

${ }^{6}$ A similar question is included in the 2004 wave of the U.S. Health and Retirement Survey (HRS).

${ }^{7}$ In Italian the question reads: "Immagini di avere 65 anni e di percepire una pensione complessiva di 1,000 euro al mese (rivalutati per l'inflazione). Sarebbe disponibile a rinunciare a metà di tale pensione per tutta la vecchiaia, in cambio una somma di 60,000 euro che le verrebbe versata immediatamente?"

${ }^{8}$ We used the official life tables provided by the Italian National Institute of Statistics (ISTAT), which computes cohort-specific mortality rates.

${ }^{9}$ It seems also a quite reasonable assumption for the medium and the long run. Indeed, 3 per cent is the figure used by European Union countries for their long-term forecasting exercises (see e.g. European Commission, 2011).

${ }^{10}$ By contrast, there has been a lot of theoretical research to determine optimal annuity demand. For instance: Ameriks et al. (2011), Horneff et al. (2009, 2010), Butler et al. (2011).

${ }^{11}$ Surveys of the development of annuity markets around the world can be found in James and Song (2002), Mackenzie (2006), and Cannon and Tonks (2008).

12 Brown (2001). 
subgroup of respondents in the 1992 wave of the U.S. Health and Retirement Survey (HRS) that covers people aged 51-61, namely those with a significant amount of wealth invested in a DC pension plan. He exploits answers to the question: "In what form do you expect to receive benefits?" He then estimates a probit model in which the binary dependent variable is the intention to annuitise. He finds that the basic tenets of the theory are confirmed, as married people with higher risk aversion, longer life expectancy and a smaller fraction of pre-annuitised retirement wealth tend to prefer annuitisation. Butler and Teppa ${ }^{13}$ perform the same exercise as Brown, ${ }^{14}$ but using actual choices instead of intentions: in particular, they consider administrative data about the annuitisation choices at retirement of Swiss workers enrolled in ten employer-sponsored pension plans. With respect to survey questions, they are administrative data have their pros and cons: they are certainly more reliable; but they usually provide much less information about the worker. Their results are in line with Brown's. 15

The paper by Hurd and Panis ${ }^{16}$ is also relevant: its methodology and results are analogous to those of Brown, and Butler and Teppa. ${ }^{17}$ However, it does not distinguish between annuitisation choices at the time of retirement and those made when the worker changes job but stays in the labour force (which is the case for about 40 per cent of the observations in their sample). Hurd and Panis use HRS data from the five waves between 1992 and $2000 .^{18}$

All these contributions shed valuable light on investors' behaviour. However, each of them suffers from (at least one of) the following limitations: (1) they do not study a representative sample of the underlying population; (2) they observe annuitisation choices (or intentions) but cannot disentangle the demand from the supply of annuities, as they do not control for annuity prices; and (3) they either do not observe the fraction of annuitised wealth held outside private pension plans ${ }^{19}$ or they measure it very imperfectly. ${ }^{20}$

The empirical approach adopted in this paper addresses these drawbacks. First, we use a sample which is representative of a large subgroup of the Italian population (namely, heads of household), and constitutes an important component of the Italian labour force. Second, experimenting with different annuity prices enables us to elicit the shape of the annuity demand schedule. Third, making the total amount of annuity benefits explicit solves the problem of controlling for differences in annuitised wealth.

13 Butler and Teppa (2007).

14 Brown, op. cit.

15 Brown, ibid.

${ }^{16}$ Hurd and Panis (2006).

${ }^{17}$ Brown, op. cit. and Butler and Teppa, op. cit.

${ }^{18}$ Respondents were asked if they had done anything with a pension right since the previous wave.

${ }^{19}$ Hurd and Panis, op. cit.; Butler and Teppa, op. cit.

${ }^{20}$ Brown, op. cit. reconstructs social security wealth using social security data on earnings and benefits histories included in the HRS. However, this data is missing for about $1 / 3$ of the sample. Moreover, he has to assume that the fraction of wealth annuitised at retirement is equal to that observed at the time of the survey. He also assumes that all retirement wealth in DB plans will be annuitised. 
780

Our paper also contributes to the literature that explores the influence of financial literacy on behaviour. Among others, Lusardi, and Lusardi and Mitchell ${ }^{21}$ convincingly argue that poor financial knowledge is the rule, rather than the exception, and that it has a significant impact on households' financial choices.

The rest of the paper is organised as follows: The next section provides a very short outline of the Italian pension system, which can be helpful to put our results in perspective; in the subsequent section we describe our data and show some preliminary univariate result; in the penultimate section we perform a more formal multivariate analysis. The final section discusses some implications of our results and offers some tentative conclusions.

\section{A short overview of the Italian pension system}

The Italian pension system has several peculiarities that make it different from those of the U.K., U.S. and Switzerland, where the other studies on annuities have been conducted.

In Italy, retirement income mainly comes from the public pay-as-you-go pension system, which is based on two main pillars. ${ }^{22}$ First, there is a relatively small noncontributory scheme, granting a minimum benefit to any person with at least 65 years and with a yearly income below a given threshold. The benefit is linearly decreasing with income and becomes zero for income levels at or above the threshold, which was equal to $€ 430$ in $2008 .^{23}$ The second pillar is a contribution-based scheme, in which the right to get a pension is conditional to a minimum number of years of contributions and/or a minimum eligibility age. The size of the benefit increases with the amount of contributions paid by the worker during his or her career. This scheme has fairly complicated rules and is the result of a lengthy reform process started in the early $1990 \mathrm{~s}^{24}$ Moreover, due to the lengthy phase-in of the reforms, the rules also change from year to year. In 2008, a worker could qualify for a contributory pension with at least 65 years of age (60 years for women) and 20 years of contribution ${ }^{25}$ and the average benefit was about $€ 1,000$ (which is why we choose such an amount in our survey question). ${ }^{26}$

${ }^{21}$ Lusardi (2008a, b) and Lusardi and Mitchell (2006).

${ }^{22}$ We do not discuss here disability pensions (which are about 25 per cent of the total pension treatments).

${ }^{23}$ The threshold itself is indexed to inflation (as of 2012, it is equal to $€ 464$ ).

${ }^{24}$ Franco (2002).

${ }^{25}$ Alternatively, he/she needed at least 40 years of contributions, or 58 years of age (59 for the selfemployed) and 35 years of contributions. Overall, about 90 per cent of old-age pensions are paid under the contributory scheme.

${ }^{26}$ The computation of benefits in the contribution-based pillar is also quite complex: due to the gradual phase-in of the pension reforms, different cohorts of workers are subject to different rules. However, focusing on those with more than 15 years of contributions in 1992, which have constituted in the past (and will still constitute for several years to come), the vast majority of those entering retirement, in 2008 pension benefits were computed as a fraction of the average of their wages of the last 10 working years. In particular, the pension/wage ratio was proportional to the years of contribution, reaching a maximum of 80 per cent with 40 years of contributions. Starting from 2012, due to a pension reform legislated in December 2011, for all the workers, including those with more than 15 years of contributions in 1992, the fraction of benefits corresponding to the period of work comprised between 2012 and retirement will be 
Apart from State-provided pensions, there are several private pension plans. Enrolment in these plans is on a voluntary basis, ${ }^{27}$ even if there are fiscal incentives for those joining, and in the case of employer-sponsored plans, most employers grant matching contributions. Assets and enrolment in these private pension schemes, although slowly increasing, are low with respect to international standards. At present, assets under management of Italian pension plans amount to 5.7 per cent of GDP, and only 28.9 per cent of private sector workers are enrolled.

\section{Data, explanatory variables and preliminary results}

The SHIW is a representative survey of the Italian population conducted by the Bank of Italy every two years. It includes information on the socio-demographic characteristics, income and wealth of about 20,000 participants. For the 2008 wave of the survey we included a module on the demand for annuities which was submitted to all the heads of household who were at least 15 years old. Actual respondents were 7,124 out of 7,977 heads of household. Our analysis focuses on heads of households who were 65 years old or younger (this makes sense given the structure of the question). In this age bracket, respondents were 4,750 out of 5,124. Overall, the nonresponse rate is quite low (with no systematic differences between respondents and non-respondents), and no one had to be dropped because of lack of information on financial wealth or other covariates. Table 1 provides a description of our sample. We should stress that, while it is representative of Italian heads of household, it is not representative of the Italian labour force. In particular, among heads of household there are relatively few women (29.6 per cent against 42.4 per cent in the labour force at large) and young people (4.9 per cent is younger than 30 y.o. against 20.8 per cent) and by consequence relatively few singles ( 13.9 per cent against 32.8 per cent). On the other hand, there seems to be almost no difference between the heads of household and the labour force when it comes to health and education.

We use the survey data to construct an indicator of the preference for annuities, which is a discrete variable taking the value of 1 for respondents who say no to the annuity even at the lowest price $(60,000)$; 2 for those who prefer the annuity at the lowest price but reject it at a higher price; 3 for those who prefer the annuity at the middle price $(80,000)$ but will not buy it at the highest price; and 4 for those who opt for the annuity even at the highest price $(100,000) .^{28}$

The answers to the annuity module are summarised in Table 2, which focuses on individuals less than 65 years old. The percentage who preferred the annuity against a lump sum of $€ 80,000$ is 69 per cent. This percentage rises to 82 per cent when the price

computed using a "notional defined contribution" rule. The Italian notional defined-contribution system is discussed in Franco, op. cit. and Franco and Sartor (2006). The December 2011 package is analysed in Visco (2011) and, more briefly, in Banca d'Italia (2012).

${ }^{27}$ As opposed to what happens, for example, in the U.K., workers cannot opt-out from the State pension system to join a private plan.

${ }^{28}$ To put these lump sums in perspective, it might be useful to know that average financial wealth for a head of household aged between 50 and 65 is equal to about $€ 40,000$. Besides financial wealth, most individuals (78 per cent) own the house in which they live. 
Table 1 Summary statistics (heads of household 65 or younger)

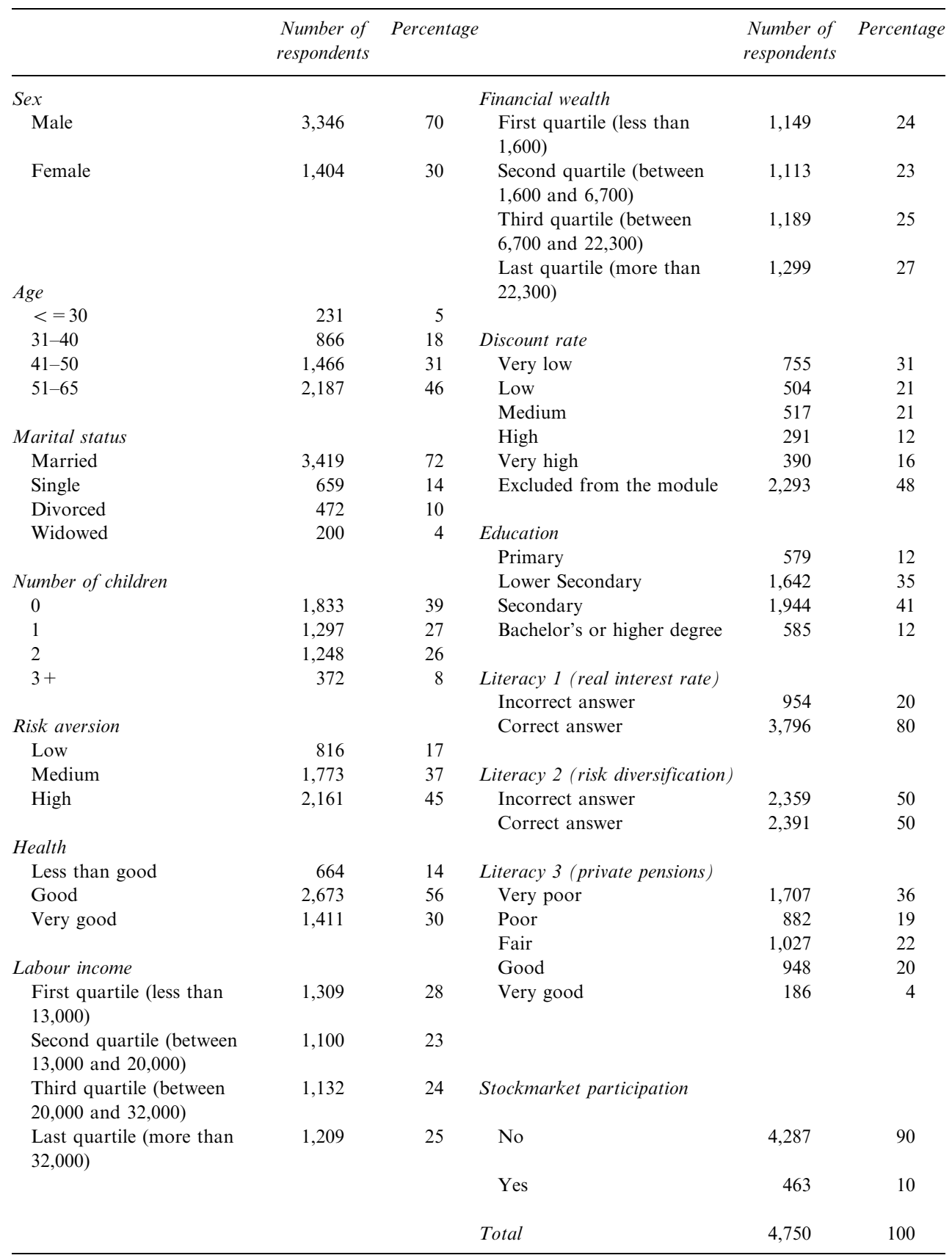

Source: SHIW 2008. 
Table 2 Demand for annuities - Participants who prefer the annuity to the lump sum (heads of household 65 or younger)

\begin{tabular}{|c|c|c|c|c|c|c|}
\hline & & Lump sur & & & Lump su & \\
\hline & Per & age of res & dents & & er of resp & lents \\
\hline & 60,000 & 80,000 & 100,000 & 60,000 & 80,000 & 100,000 \\
\hline All respondents & 81.9 & 69.4 & 39.9 & 3,891 & 3,296 & 1,897 \\
\hline Sex & & & & & & \\
\hline Male & 82.1 & 70.1 & 40.8 & 2,738 & 2,339 & 1,362 \\
\hline Female & 81.5 & 67.6 & 37.8 & 1,154 & 956 & 535 \\
\hline Age & & & & & & \\
\hline$<=30$ & 77.8 & 63.5 & 30.3 & 180 & 147 & 70 \\
\hline $31-40$ & 77.4 & 64.3 & 33.4 & 671 & 557 & 289 \\
\hline $41-50$ & 81.9 & 69.9 & 39.1 & 1,201 & 1,025 & 574 \\
\hline $51-65$ & 85.5 & 73.3 & 46.6 & 1,870 & 1,602 & 1,019 \\
\hline Marital status & & & & & & \\
\hline Married & 82.1 & 69.6 & 40.8 & 2,806 & 2,381 & 1,394 \\
\hline Single & 82.8 & 68.7 & 36.3 & 545 & 453 & 239 \\
\hline Divorced & 81.2 & 70.8 & 40.2 & 383 & 334 & 190 \\
\hline Widowed & 77.6 & 64.0 & 40.4 & 155 & 128 & 81 \\
\hline Number of children & & & & & & \\
\hline 0 & 82.3 & 68.9 & 38.8 & 1,508 & 1,262 & 711 \\
\hline 1 & 83.1 & 72.0 & 42.4 & 1,078 & 934 & 550 \\
\hline 2 & 81.3 & 68.9 & 39.6 & 1,015 & 860 & 495 \\
\hline $3+$ & 78.1 & 65.0 & 39.0 & 290 & 242 & 145 \\
\hline Risk aversion & & & & & & \\
\hline Low & 82.6 & 72.2 & 45.0 & 674 & 589 & 367 \\
\hline Medium & 83.6 & 71.7 & 38.7 & 1,482 & 1,271 & 687 \\
\hline High & 80.4 & 66.7 & 39.2 & 1,738 & 1,442 & 847 \\
\hline Health & & & & & & \\
\hline Less than good & 78.7 & 62.7 & 35.5 & 523 & 416 & 235 \\
\hline Good & 82.3 & 69.8 & 38.6 & 2,199 & 1,867 & 1,030 \\
\hline Very good & 82.7 & 71.5 & 44.6 & 1,167 & 1,009 & 629 \\
\hline Labour income & & & & & & \\
\hline First quartile & 77.0 & 62.6 & 37.3 & 915 & 743 & 443 \\
\hline Second quartile & 82.6 & 66.4 & 35.5 & 1,009 & 811 & 433 \\
\hline Third quartile & 82.7 & 72.7 & 38.5 & 957 & 841 & 446 \\
\hline Last quartile & 85.1 & 75.9 & 49.1 & 1,008 & 899 & 581 \\
\hline Financial wealth & & & & & & \\
\hline First quartile & 72.2 & 56.3 & 29.8 & 858 & 669 & 354 \\
\hline Second quartile & 84.5 & 70.7 & 41.3 & 1,003 & 839 & 491 \\
\hline Third quartile & 85.6 & 73.8 & 42.7 & 1,046 & 902 & 521 \\
\hline Last quartile & 85.9 & 78.0 & 47.0 & 991 & 899 & 542 \\
\hline
\end{tabular}


Table 2 (continued)

\begin{tabular}{|c|c|c|c|c|c|c|}
\hline & & Lump sut & & & Lump su & \\
\hline & $\mathrm{Per}$ & age of re. & dents & & er of resp & lents \\
\hline & 60,000 & 80,000 & 100,000 & 60,000 & 80,000 & 100,000 \\
\hline Discount rate & & & & & & \\
\hline Low & 88.5 & 80.2 & 52.8 & 459 & 433 & 250 \\
\hline Medium & 85.7 & 72.8 & 31.0 & 443 & 376 & 160 \\
\hline High & 77.0 & 57.4 & 23.3 & 224 & 167 & 68 \\
\hline Very high & 57.6 & 44.2 & 20.9 & 225 & 172 & 81 \\
\hline Excluded from the module & 82.2 & 68.5 & 40.3 & 1,885 & 1,571 & 924 \\
\hline Education & & & & & & \\
\hline Primary & 77.9 & 63.5 & 32.0 & 411 & 335 & 169 \\
\hline Lower Secondary & 79.8 & 64.2 & 33.4 & 1,278 & 1,029 & 535 \\
\hline Higher Secondary & 83.9 & 72.9 & 43.8 & 1,607 & 1,396 & 838 \\
\hline Bachelor or higher degree & 83.4 & 76.5 & 50.0 & 480 & 441 & 288 \\
\hline Literacy 1 (real interest rate) & & & & & & \\
\hline Incorrect answer & 78.1 & 62.0 & 32.1 & 745 & 592 & 306 \\
\hline Correct answer & 82.9 & 71.3 & 42.0 & 3,148 & 2,707 & 1,595 \\
\hline Literacy 2 (risk diversification & & & & & & \\
\hline Incorrect answer & 81.5 & 68.5 & 42.7 & 1,923 & 1,616 & 1,008 \\
\hline Correct answer & 82.3 & 70.2 & 37.3 & 1,968 & 1,679 & 892 \\
\hline Literacy 3 (private pensions) & & & & & & \\
\hline Very poor & 76.7 & 61.7 & 34.0 & 1,309 & 1,054 & 581 \\
\hline Poor & 84.0 & 72.0 & 43.8 & 741 & 635 & 386 \\
\hline Fair & 84.6 & 74.4 & 39.5 & 869 & 764 & 406 \\
\hline Good & 86.0 & 75.1 & 46.6 & 816 & 712 & 442 \\
\hline Very good & 89.7 & 77.6 & 50.1 & 167 & 144 & 93 \\
\hline Stock market participation & & & & & & \\
\hline Yes & 81.5 & 73.2 & 42.5 & 378 & 339 & 197 \\
\hline No & 82.0 & 69.0 & 39.7 & 3,514 & 2,957 & 1,701 \\
\hline
\end{tabular}

Source: SHIW 2008.

of the annuity is reduced to 60,000 and falls to 40 per cent when the price increases to 100,000. (It should be remarked that any question on income in SHIW has to be understood as referring to magnitudes that are net of taxes; this is explicitly told to the interviewee at the beginning of the interview. $)^{29}$

As a first step, we look at simple unconditional correlations between our measure of annuity preference and some individual and household characteristics which economic theory suggests are potentially relevant.

${ }^{29}$ Moreover, under the Italian pension law there is no difference in the taxation of the lump sum and of the annuity: in both cases, pension wealth at retirement is subject to a proportional tax of 15 per cent. Therefore, we should not be concerned with the tax issue. 
Some of the results of the univariate analysis are at odds with rationality. First, women and younger cohorts do not seem to prefer annuities more than men and older cohorts (in the case of young people, quite the contrary is true), as should be the case since both groups enjoy a higher life expectancy at retirement, which in turn implies that the expected present value of a given stream of life-long payments is higher. Second, marital status and the presence of children do not influence annuity demand. ${ }^{30}$ This result holds even if attention is restricted to older people (aged between 50 and 65), for whom actual family status is likely to be equal to the one expected at 65. According to theory, however, married people and people with children should have a reduced annuity demand, as they can at least in part obtain insurance against longevity risk within the family, either for altruistic of for selfinterested reasons. ${ }^{31}$ Third, our measure of annuity preference does not increase with risk aversion, even if the insurance against longevity risk provided by annuity contracts should be highly valued by risk-averse individuals. In particular, our proxy for risk aversion comes from the following question, included in the SHIW survey:

In managing your financial investments, would you say you have a preference for investments that offer: (a) Very high returns, but with a high risk of losing part of the capital; (b) A good return, but also a fair degree of protection for the invested capital; (c) A fair return, with a good degree of protection for the invested capital; (d) Low returns, with a low risk of losing the invested capital. $^{32}$

Other results are instead in line with rationality. First, health status has a strong positive impact on annuity demand (e.g. against an $€ 80,000$ lump sum, 72 per cent of people who report they are in "very good health" choose to annuitise; this figure goes down to 63 per cent for those with a health status "less than good"). Indeed people in good shape should value annuities relatively more, as they expect to receive more annuity payments. Second, both higher income and higher wealth imply an increased propensity to annuitise, with a stronger effect at the bottom of the distribution. From a theoretical point of view, this finding has two complementary explanations: (i) to reach a given desired fraction of annuitised wealth, wealthier people need to buy a greater amount of annuities; (ii) poorer people should optimally annuitise a lower fraction of their wealth, because they have a higher probability of facing a liquidity problem sometime during retirement. ${ }^{33}$ In general, it is not possible to borrow against future annuity payments. Therefore, people who fear they will face a binding liquidity constraint at a certain point during retirement (e.g. due to out-of-pocket medical expenditures) should prefer not to annuitise their pension wealth. ${ }^{34}$ Of course our

\footnotetext{
${ }^{30}$ These results confirm similar findings by Butler and Teppa, op. cit. and Johnson et al (2004).

${ }^{31}$ E.g. through implicit contracts across generations, as in Kotlikoff and Spivak (1981).

${ }^{32}$ Individuals who answered (a) were considered low risk aversion individuals; those who answered (b) or (c) were considered medium risk aversion individuals; those who answered (d) were considered high risk aversion individuals.

${ }^{33}$ Income and wealth are considered as dummies to pick up possible non-linearities, for example due to liquidity constraints.

${ }^{34}$ Turra and Mitchell (2005).
} 
interpretation of the data is valid to the extent that today's health and wealth are correlated to the expectations of the respondents concerning their own health and wealth at 65 . Therefore, as we did for family status, we checked that the results for health and wealth are not affected if we focus on the 51-65 age class. Third, we find that people who discount future consumption at a higher rate tend to prefer a lump sum over the annuity, where we use the participants' answer to the following question as a proxy for the discount rate: ${ }^{35}$

"You have won the lottery and will receive a sum equal to your household's net yearly revenue. You will receive the money in a year's time. However, if you give up part of the sum you can collect the rest of your win immediately. To obtain the money immediately would you give up 20 per cent of your win?" "What about 10 per cent?" "And 5 per cent?" “Just 2 per cent?",36

Overall, our data question the assumption that households are able to make the annuitisation decision on the basis of a full evaluation of the effects and likelihood of all relevant future events, maximising the expected discounted value of present and future utility. This is consistent with previous evidence showing that many individuals are not able to do even simple economic computations, and lack knowledge of even the most basic economic concepts. ${ }^{37}$ This could explain some of the above-mentioned correlations: for example, older people might have a higher propensity to annuitise because they have already spent more time planning for retirement, so they are better equipped to understand annuities and their advantages. The negative correlation between risk aversion and annuity demand may also be due to behavioural biases. In particular, Brown et al. ${ }^{38}$ find the same relationship as we do looking at U.S. survey data, and argue that some people might incorrectly interpret (or "frame") an annuity as a bet on one's life span, instead of a hedge against longevity risk.

A sign of the importance of cognitive factors is that higher educational qualifications come with a greater propensity to annuitise: 64 per cent of participants with primary education say they would prefer the annuity to a lump sum of $€ 80,000$; this figure rises to 77 per cent for those with a bachelor's or higher degree. To better assess the role of financial literacy in explaining annuity demand, we included some ad hoc questions in the Bank of Italy's Survey. In particular, we build a first dummy variable which equals 1 if the respondent answers the following question correctly:

Imagine leaving 1,000 euros in a current account that pays 1 per cent interest and has no charges. Imagine that inflation is running at 2 per cent. Do you think that if you withdraw the money in a year's time you will be able to buy the same

\footnotetext{
${ }^{35}$ The question was put to a randomised subset (about 50 per cent of the total) of our sample. See also Warner and Pleeter (2001) for a similar result.

${ }^{36}$ We used answers to the question to build an ordinal proxy for the discount rate. In particular, it is considered "very high" if the person is willing to give away 20 per cent of the sum, "high" if the person is willing to give away 10 per cent, "medium" if he is willing to give away 10 per cent, "low" if he is willing to give away 2 per cent or less.

${ }^{37}$ Lusardi (2008a, b), Lusardi op cit.

${ }^{38}$ Brown et al. (2008).
} 
amount of goods as if you spent the 1,000 euros today? (a) Yes; (b) No, I will be able to buy less; (c) No, I will be able to buy more; (d) Don't know.

The second dummy is equal to one if the respondent answers correctly to the following question:

Which of the following investment strategies do you think entails the greatest risk of losing your capital? (a) Investing in the shares of a single company;

(b) Investing in the shares of more than one company; (c) Don't know.

These two questions were first used in the 2004 HRS survey. ${ }^{39}$ They assess the knowledge of two very basic economic concepts: inflation and risk diversification. Being able to understand inflation risk is crucial to evaluate correctly whether an annuity is better value than a lump sum. Indeed, people who respond incorrectly to the first question may not understand that the real returns of some asset classes (such as a simple bank deposit) are dented by inflation: this might induce them to underestimate the value of a real annuity (such as the one offered to our respondents). Our data suggest that this is actually the case.

The sign of the relationship between knowledge of the risk diversification principle and annuitisation is instead less straightforward. On one side, those unable to understand the principle of portfolio diversification are unlikely to profit from investing in financial markets: for them, the value of a lump sum (which depends on how it is invested during the post-retirement period) might be low relative to the value of the annuity. Therefore, if they are aware of their financial ignorance, they should prefer the annuity. On the other side, a minimum degree of financial sophistication is also required in order to understand the value of annuitisation as a way to avoid longevity risk. As a matter of fact, at least looking at simple correlations, in our sample, annuity demand is lower for people answering the risk diversification question correctly. The point that the relationship between financial knowledge and propensity to annuitise can go in either directions has been stressed by Brown and Agnew et al. ${ }^{40}$

We also consider a further aspect of financial literacy, by measuring the extent to which respondents understand the basic features of the Italian private pension system. This is likely to be important for the decision to annuitise, as private pension plans are the main financial instruments offering a payout in an annuity form. In particular, we consider the number of correct answers that the respondent gives to the following questions:

Which of the following statements concerning supplementary pension schemes do you believe to be true? (1) Investing in a supplementary pension plan has tax advantages compared with investment funds in general. (2) Part of the capital can be withdrawn at the time of retirement. (3) Some pension funds guarantee restitution of the capital paid in. (4) Pension funds guarantee a fixed percentage of the last salary.

\footnotetext{
${ }^{39}$ Lusardi and Mitchell, op. cit.

${ }^{40}$ Brown $(2007,2008)$ and Agnew et al. (2008).
} 
Those who perform badly in this test of pension literacy appear less likely to opt for the annuity.

Finally, as another proxy for the degree of financial education, we also added a dummy taking value of one if the individual owns stocks. ${ }^{41}$ It turns out that owning stocks correlates positively with the propensity to annuitise, albeit very slightly.

\section{Econometric analysis}

\section{Empirical methodology}

In this section, we assess the extent to which the simple correlation results highlighted above are robust to a more formal multivariate analysis.

Let us indicate $Y_{i}$ our dependent variable (the degree of annuity preference of individual $i$ ). As we remarked above, $Y_{i}=1$ if $i$ always chooses the lump sum, $Y_{i}=2$ if $i$ prefers a $€ 80,000$ lump sum to the annuity, but prefers the annuity to the $€ 60,000$ lump sum, $Y_{i}=3$ if $i$ prefers a $€ 100,000$ lump sum to the annuity, but prefers the annuity to the 80,000 lump sum, and $Y_{i}=4$ if $i$ always chooses the annuity.

Given the ordered and discrete nature of our independent variable, we consider an ordered probit model. That is, we assume the choice of the individual is determined by a latent variable $Y_{i}^{*}=\beta^{\prime} X_{i}+\varepsilon_{i}$ (with $\varepsilon_{i}$ normal conditional to $X_{i}$ ) according to a simple rule:

$$
\begin{array}{ll}
Y_{i}=1 & \text { if } Y_{i}^{*} \leqslant K_{1} \\
Y_{i}=2 & \text { if } K_{1} \leqslant Y_{i}^{*} \leqslant K_{2} \\
Y_{i}=3 & \text { if } K_{2} \leqslant Y_{i}^{*} \leqslant K_{3} \\
Y_{i}=4 & \text { if } Y_{i}^{*} \geqslant K_{3},
\end{array}
$$

where $K_{1}<K_{2}<K_{3}$ are unknown constants. This implies that:

$$
\begin{aligned}
\operatorname{Pr}\left(Y_{i}=1 \mid X_{i}\right) & =\operatorname{Pr}\left(\beta^{\prime} X_{i}+\varepsilon_{i}<K_{1}\right) \\
& =\operatorname{Pr}\left(\varepsilon_{i}<K_{1}-\beta^{\prime} X_{i}\right) \\
& =\Phi\left(K_{1}-\beta^{\prime} X_{i}\right),
\end{aligned}
$$

where $\Phi$ is the cumulative density function of the normal distribution. In the same way, one has:

$$
\begin{aligned}
& \operatorname{Pr}\left(Y_{i}=2 \mid X_{i}\right)=\Phi\left(K_{1}-\beta^{\prime} X_{i}\right)-\Phi\left(K_{2}-\beta^{\prime} X_{i}\right) \\
& \operatorname{Pr}\left(Y_{i}=3 \mid X_{i}\right)=\Phi\left(K_{2}-\beta^{\prime} X_{i}\right)-\Phi\left(K_{3}-\beta^{\prime} X_{i}\right) \\
& \operatorname{Pr}\left(Y_{i}=4 \mid X_{i}\right)=1-\Phi\left(K_{3}-\beta^{\prime} X_{i}\right) .
\end{aligned}
$$

We estimate the model, as usual, with maximum-likelihood. ${ }^{42}$

\footnotetext{
${ }^{41}$ As suggested by Inkmann et al. (2011).

${ }^{42}$ See Wooldridge (2002).
} 
Results

Our estimates mostly confirm the findings of the univariate analysis (Table 3). ${ }^{43}$ Contrary to what theory predicts, gender, marital status, the presence of children and risk aversion do not influence annuity demand. Instead, bad health and a low level of income and financial wealth reduce annuity preferences in a statistically significant way, as predicted by theory. ${ }^{44}$ Formal education and all our proxies for financial literacy are significant. In particular, understanding the risk diversification principle, and stockmarket participation reduce the propensity to annuitise. The contrary is true for schooling and for the other literacy variables (i.e. understanding the effects of inflation and understanding how private pension schemes work). All in all, these results confirm our caveat that there is not an a priori presumption that the more financially educated individuals have a stronger preference for annuitisation.

To assess the economic/quantitative importance of the independent variables, in Table 3 we also look at how they affect the probability of not being a $Y_{i}=1$ individual (symmetrically, in the table we also provide the effect on the probability of being a $Y_{i}=4$ individual). The effect is particularly sizeable in the case of wealth and schooling. The probability of rejecting the annuity even for the lowest lump sum is 6.5 percentage points lower for an individual in the second income quartile than for an individual in the first quartile ${ }^{45}$ it is 6.1 percentage points lower for an individual with a high school diploma than for an individual who only completed the lower secondary school. Concerning financial literacy, the effect on the probability of accepting the annuity in exchange for the lowest lump sum is also sizeable.

\section{The demand schedule}

To further illustrate the economic significance of the effects, we can compute and compare the estimated demand schedule for individuals with different characteristics. For example, let us consider an individual holding a bachelor's degree, who is in the highest wealth quartile, and has the highest possible scores in all dimensions of financial literacy. ${ }^{46}$ According to the estimated model, this individual displays a high propensity to annuitise at all prices: ${ }^{47}$ the estimated probability of buying an annuity

${ }^{43}$ In all the reported estimations, we use survey weights to ensure that the results are valid for the underlying population. The use of weights in order to correct for unequal probabilities of selection among sampling units is discussed, among others, in Deaton (1997). The weighting scheme adopted in the Bank of Italy Survey is explained in detail in Faiella and Gambacorta (2007).

${ }^{44}$ In an early version of the regressions we added real estate wealth among the regressors but, contrary to financial wealth - which is more liquid - it is never significant, so we dropped it from our preferred specification.

${ }^{45}$ Income and wealth quartiles are ordered from the poorest (the first quartile) to the richest (the last quartile).

${ }^{46}$ This individual is male, married with children, in good health, with an average degree of risk aversion, and is over 60 years old.

${ }^{47}$ Of course, the choice of the benchmark is quite arbitrary, and it only matters as a way to clarify and show the results of the multivariate analysis. 
Table 3 Demand for annuities: Ordered probit model (heads of household aged 65 or younger)

\begin{tabular}{|c|c|c|c|}
\hline & $\begin{array}{c}\text { Parameter } \\
\text { estimates }\end{array}$ & $\begin{array}{l}\text { Marginal effects on the } \\
\text { probability of rejecting the } \\
\text { annuity even at the lowest } \\
\text { lump sum }\end{array}$ & $\begin{array}{c}\text { Marginal effects on the } \\
\text { probability of choosing the } \\
\text { annuity even at the highest } \\
\text { lump sum }\end{array}$ \\
\hline \multicolumn{4}{|l|}{ Sex } \\
\hline Female & - & - & - \\
\hline Male & -0.0654 & 0.0166 & -0.024 \\
\hline \multicolumn{4}{|l|}{ Age (years) } \\
\hline$<=30$ & - & - & - \\
\hline $31-40$ & 0.0064 & -0.0019 & 0.0022 \\
\hline $41-50$ & $0.1719 *$ & $-0.047^{*}$ & $0.0619 *$ \\
\hline $51-65$ & $0.3569 * * *$ & $-0.0903 * * *$ & $0.1316^{* * *}$ \\
\hline \multicolumn{4}{|l|}{ Marital status } \\
\hline Not married & - & - & - \\
\hline Married & -0.0689 & 0.017 & -0.0255 \\
\hline \multicolumn{4}{|l|}{ Children } \\
\hline No children & - & - & - \\
\hline One or more children & 0.0064 & -0.0016 & 0.0023 \\
\hline \multicolumn{4}{|l|}{ Risk aversion } \\
\hline Low & - & - & - \\
\hline Medium & 0.1565 & -0.04 & 0.0573 \\
\hline High & 0.0777 & -0.0205 & 0.0282 \\
\hline \multicolumn{4}{|l|}{ Health } \\
\hline Very good or good & - & - & - \\
\hline Less than good & $-0.1197^{*}$ & $0.0311^{*}$ & $-0.0437^{*}$ \\
\hline \multicolumn{4}{|l|}{ Household labour income } \\
\hline First quartile & - & - & - \\
\hline Second quartile & $0.177 * * *$ & $-0.0463^{* * *}$ & $0.065 * * *$ \\
\hline Third quartile & $0.1615^{* *}$ & $-0.0425 * *$ & $0.0592 * *$ \\
\hline Last quartile & $0.2259 * * *$ & $-0.0578 * * *$ & $0.0835^{* * *}$ \\
\hline \multicolumn{4}{|l|}{ Financial wealth } \\
\hline First quartile & - & - & - \\
\hline Second quartile & $0.2635 * * *$ & $-0.0698 * * *$ & $0.0965 * * *$ \\
\hline Third quartile & $0.264 * * *$ & $-0.0699 * * *$ & $0.0966^{* * *}$ \\
\hline Last quartile & $0.2495 * * *$ & $-0.0665^{* * *}$ & $0.0912 * * *$ \\
\hline \multicolumn{4}{|l|}{ Education } \\
\hline Primary & - & - & - \\
\hline Lower Secondary & 0.0452 & -0.0126 & 0.0161 \\
\hline Secondary & $0.2366 * * *$ & $-0.0612 * * *$ & $0.0869 * * *$ \\
\hline Bachelor or higher degree & $0.3222 * * *$ & $-0.0803 * * *$ & $0.1194 * * *$ \\
\hline \multicolumn{4}{|l|}{ Literacy 1 (real interest rate) } \\
\hline Incorrect answer & - & - & - \\
\hline Correct answer & $0.153 * * *$ & $-0.0398 * * *$ & $0.0559 * * *$ \\
\hline
\end{tabular}


Table 3 (continued)

\begin{tabular}{|c|c|c|c|}
\hline & $\begin{array}{c}\text { Parameter } \\
\text { estimates }\end{array}$ & $\begin{array}{l}\text { Marginal effects on the } \\
\text { probability of rejecting the } \\
\text { annuity even at the lowest } \\
\text { lump sum }\end{array}$ & $\begin{array}{c}\text { Marginal effects on the } \\
\text { probability of choosing the } \\
\text { annuity even at the highest } \\
\text { lump sum }\end{array}$ \\
\hline \multicolumn{4}{|c|}{ Literacy 2 (risk diversification) } \\
\hline Incorrect answer & - & - & - \\
\hline Correct answer & $-0.225^{* * *}$ & $0.056^{* * *}$ & $-0.0827 * * *$ \\
\hline \multicolumn{4}{|c|}{ Literacy 3 (private pensions) } \\
\hline No correct answer & - & - & - \\
\hline 1 correct answer & $0.1761 * * *$ & $-0.0446^{* * *}$ & $0.0652 * * *$ \\
\hline 2 correct answers & 0.0945 & -0.0248 & 0.0346 \\
\hline 3 correct answers & $0.1922 * * *$ & $-0.0483^{* * *}$ & $0.0713^{* * *}$ \\
\hline 4 correct answers & $0.2867 * * *$ & $-0.069 * * *$ & $0.1072 * *$ \\
\hline \multicolumn{4}{|l|}{ Stock market participation } \\
\hline No & - & - & - \\
\hline Yes & $-0.1952 * *$ & $0.0523 * *$ & $-0.0701 * *$ \\
\hline Number of observations & 4,750 & 4,750 & 4,750 \\
\hline Pseudo $R^{2}$ & 0.030 & 0.030 & 0.030 \\
\hline
\end{tabular}

Note: Significance levels: 1 per cent $(* * *) ; 5$ per cent $(* *), 10$ per cent $(*)$.

even at the highest price is 55.8 per cent, increasing to 82.8 per cent against a lump sum of $€ 80,000$ and to 91.5 per cent against a lump sum of $€ 60,000$. We can then compare our benchmark with other individuals who are similar in all respects except that: (1) they belong to the lowest wealth quartile: this implies that the probability of going for the annuity at the mid price goes down from 82.8 per cent to 75.1 per cent; or (2) have only a lower secondary school diploma (the probability of choosing the annuity at the mid price is equal to 73.6 per cent); or (3) get the worst possible scores in all aspects of financial literacy (in this case, the probability of choosing the annuity at the mid price is 81.6 per cent). An individual who differs from the benchmark for all three aspects has a probability of choosing the annuity at the mid price equal to only 63.9 per cent (Figure 1).

The annuity demand appears to be quite elastic with respect to prices. It is particularly so at high prices and for the most vulnerable people: it is 33 per cent for our benchmark, 40 per cent for a person belonging to the lowest wealth quartile, 41 per cent for one having only a primary school diploma, 32 per cent for a person with low pension literacy, and arrives at 51 per cent for a person who has all these three characteristics at the same time (i.e. he is in the lowest wealth quartile, no high school diploma and very poor financial literacy). ${ }^{48}$

${ }^{48}$ As in the previous exercise, all these individuals are, in all other respects, similar to the benchmark. 


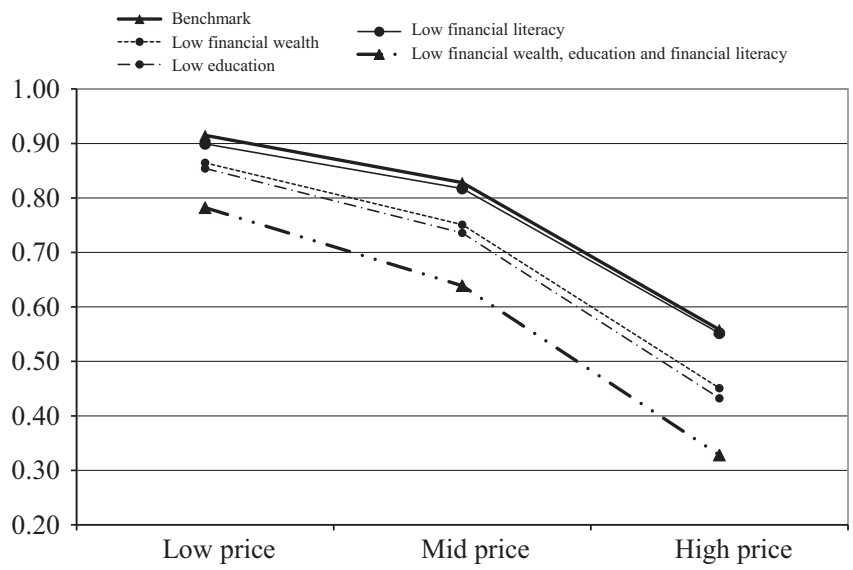

Figure 1. Probability of choosing the annuity as a function of price.

\section{Robustness checks}

First, we check that the results of the previous section do not change if we enlarge the sample to consider all the respondents (therefore including those above 65).

As a second exercise, we restrict the sample to respondents in the 51-65 age bracket. This is potentially interesting because for these individuals the values of most variables should be very close to the (subjectively) expected values at retirement.

In this regression, some differences emerge with respect to the baseline (Table 4). On the one hand, the role of children now appears to be significantly negative, lending some support to the argument that informal within-family arrangements can be seen as a substitute for market-provided insurance against longevity risk. This mechanism might be attenuated when using our baseline sample simply because many younger respondents included in the larger sample plan or expect to increase their number of children (therefore, for these respondents the actual number of children is a poor proxy of the expected number of children at retirement). On the other hand, health loses significance, ${ }^{49}$ and education, while still significant, seems to play a lesser role.

We also estimate a richer specification (see Table 5), in which we add our proxy for the discount rate to the independent variables. This comes at the cost of a much lower number of observations, as the question concerning the discount rate was posed only to a (randomised) subset of respondents. It turns out that, as expected, a higher discount rate implies lower annuity demand. Instead, health and two of the financial literacy variables lose their significance. This suggests that the correlation between financial literacy and annuity demand is partly due to the fact that a low discount rate has a positive impact not only on the latter but also on the former, as those who do not care about future well-being are unlikely to invest time and effort in

${ }^{49}$ One of the reasons for this is that (both in general and in our data) the correlation between health and income and the correlation between health and wealth are higher for older people than for younger people. 
Table 4 Demand for annuities: Ordered probit model (heads of household between 51 and 65)

\begin{tabular}{|c|c|c|c|}
\hline & $\begin{array}{c}\text { Parameter } \\
\text { estimates }\end{array}$ & $\begin{array}{l}\text { Marginal effects on the } \\
\text { probability of rejecting the } \\
\text { annuity even at the lowest } \\
\text { lump sum }\end{array}$ & $\begin{array}{c}\text { Marginal effects on the } \\
\text { probability of choosing the } \\
\text { annuity even at the highest } \\
\text { lump sum }\end{array}$ \\
\hline \multicolumn{4}{|l|}{ Sex } \\
\hline Female & - & - & - \\
\hline Male & -0.1323 & 0.0287 & -0.0502 \\
\hline \multicolumn{4}{|l|}{ Age (years) } \\
\hline$<=30$ & - & - & - \\
\hline $31-40$ & - & - & - \\
\hline $41-50$ & - & - & - \\
\hline $51-65$ & - & - & - \\
\hline \multicolumn{4}{|l|}{ Marital status } \\
\hline Not married & - & - & - \\
\hline Married & -0.0239 & 0.0052 & -0.0091 \\
\hline \multicolumn{4}{|l|}{ Children } \\
\hline No children & - & - & - \\
\hline One or more children & $-0.1533^{* *}$ & $0.0333 * *$ & $-0.0581^{* *}$ \\
\hline \multicolumn{4}{|l|}{ Risk aversion } \\
\hline Low & - & - & - \\
\hline Medium & -0.1919 & 0.0417 & -0.0728 \\
\hline High & -0.0976 & 0.0212 & -0.037 \\
\hline \multicolumn{4}{|l|}{ Health } \\
\hline Very good or good & - & - & - \\
\hline Less than good & -0.0829 & 0.018 & -0.0314 \\
\hline \multicolumn{4}{|l|}{ Household labour income } \\
\hline First quartile & - & - & - \\
\hline Second quartile & 0.1449 & -0.0315 & 0.055 \\
\hline Third quartile & $0.2878 * * *$ & $-0.0625^{* * *}$ & $0.1091 * * *$ \\
\hline Last quartile & $0.3832 * * *$ & $-0.0833^{* * *}$ & $0.1453^{* * *}$ \\
\hline \multicolumn{4}{|l|}{ Financial wealth } \\
\hline First quartile & - & - & - \\
\hline Second quartile & $0.1926^{*}$ & $-0.0419^{*}$ & $0.073^{*}$ \\
\hline Third quartile & $0.2641 * * *$ & $-0.0574 * * *$ & $0.1001 * * *$ \\
\hline Last quartile & $0.4065 * * *$ & $-0.0883^{* * *}$ & $0.1541 * * *$ \\
\hline \multicolumn{4}{|l|}{ Education } \\
\hline Primary & - & - & - \\
\hline Lower Secondary & 0.0629 & -0.0137 & 0.0239 \\
\hline Secondary & $0.1585^{*}$ & $-0.0344^{*}$ & $0.0601 *$ \\
\hline Bachelor or higher degree & 0.1639 & -0.0356 & 0.0621 \\
\hline \multicolumn{4}{|l|}{ Literacy 1 (real interest rate) } \\
\hline Incorrect answer & - & - & - \\
\hline Correct answer & 0.0643 & -0.014 & 0.0244 \\
\hline
\end{tabular}


Table 4 (continued)

\begin{tabular}{|c|c|c|c|}
\hline & $\begin{array}{c}\text { Parameter } \\
\text { estimates }\end{array}$ & $\begin{array}{c}\text { Marginal effects on the } \\
\text { probability of rejecting the } \\
\text { annuity even at the lowest } \\
\text { lump sum }\end{array}$ & $\begin{array}{c}\text { Marginal effects on the } \\
\text { probability of choosing the } \\
\text { annuity even at the highest } \\
\text { lump sum }\end{array}$ \\
\hline \multicolumn{4}{|c|}{ Literacy 2 (risk diversification) } \\
\hline Incorrect answer & - & - & - \\
\hline Correct answer & $-0.2772 * * *$ & $0.0602 * * *$ & $-0.1051 * * *$ \\
\hline \multicolumn{4}{|c|}{ Literacy 3 (private pensions) } \\
\hline No correct answer & - & - & - \\
\hline 1 correct answer & $0.2686^{* * *}$ & $-0.0584 * * *$ & $0.1018 * * *$ \\
\hline 2 correct answers & -0.0816 & 0.0177 & -0.0309 \\
\hline 3 correct answers & -0.0092 & 0.002 & -0.0035 \\
\hline 4 correct answers & $0.4371 * * *$ & $-0.095^{* *}$ & $0.1657 * * *$ \\
\hline \multicolumn{4}{|l|}{ Stock market participation } \\
\hline No & - & - & - \\
\hline Yes & -0.1777 & 0.0386 & -0.0674 \\
\hline Number of observations & 2,187 & 2,187 & 2,187 \\
\hline Pseudo $R^{2}$ & 0.030 & 0.030 & 0.030 \\
\hline
\end{tabular}

Note: Significance levels: 1 per cent $(* * *) ; 5$ per cent $(* *), 10$ per cent $(*)$.

acquiring financial knowledge. ${ }^{50}$ Quantitatively, the effect of a higher discount rate is paramount: with respect to an individual with a "low" discount rate, the probability of rejecting the annuity and choosing the $€ 60,000$ lump sum is increased by 7.5 percentage points if the discount rate is "medium", by 16.2 percentage points if it is "high", and by 25.5 percentage points if it is "very high".

As a final exercise, we also estimate, instead of our baseline multinomial model, simpler binomial models. In particular, we consider three binomial probit models, in which the dependent variable takes value of one if the individual chooses the annuity against a lump sum of $€ 60,000, € 80,000$ and $€ 100,000$, respectively. The three estimates (shown in Table 6) confirm our baseline results.

To summarise, across all the samples and specifications that we used, the importance of wealth, schooling and financial literacy is confirmed.

\section{Estimated annuity demand and actual annuitisation choices}

Prima facie, the annuity demand schedule that we estimated from our survey data is in contrast with the thinness of the Italian annuity market. In fact, as discussed in Guazzarotti and Tommasino, ${ }^{51}$ the number of outstanding annuity contracts is very

\footnotetext{
${ }^{50}$ As an aside, it should be noted that the fact that the coefficient on health also loses significance is consistent with the view that one's health is determined by one's investments in "health capital", which in turn depend negatively on the personal discount rate (see Grossman, 2000).

${ }^{51}$ Guazzarotti and Tommasino (2008).
} 
Table 5 Demand for annuities: Ordered probit model controlling for the discount rate (heads of household aged 65 or younger)

\begin{tabular}{|c|c|c|c|}
\hline & $\begin{array}{c}\text { Parameter } \\
\text { estimates }\end{array}$ & $\begin{array}{l}\text { Marginal effects on the } \\
\text { probability of rejecting the } \\
\text { annuity even at the lowest } \\
\text { lump sum }\end{array}$ & $\begin{array}{c}\text { Marginal effects on the } \\
\text { probability of choosing the } \\
\text { annuity even at the highest } \\
\text { lump sum }\end{array}$ \\
\hline \multicolumn{4}{|l|}{$\operatorname{Sex}$} \\
\hline Female & - & - & - \\
\hline Male & -0.0483 & 0.0114 & -0.0167 \\
\hline \multicolumn{4}{|l|}{ Age (years) } \\
\hline$<=30$ & - & - & - \\
\hline $31-40$ & -0.1913 & 0.053 & -0.0631 \\
\hline $41-50$ & 0.0969 & -0.0242 & 0.0336 \\
\hline $51-65$ & $0.3825 * * *$ & $-0.0847 * *$ & $0.1366^{* * *}$ \\
\hline \multicolumn{4}{|l|}{ Marital status } \\
\hline Not married & - & - & - \\
\hline Married & -0.0151 & 0.0035 & -0.0052 \\
\hline \multicolumn{4}{|l|}{ Children } \\
\hline No children & - & - & - \\
\hline One or more children & -0.0386 & 0.009 & -0.0134 \\
\hline \multicolumn{4}{|l|}{ Risk aversion } \\
\hline Low & - & - & - \\
\hline Medium & -0.1863 & 0.0352 & -0.0666 \\
\hline High & -0.3592 & 0.0738 & -0.1273 \\
\hline \multicolumn{4}{|l|}{ Health } \\
\hline Very good or good & - & - & - \\
\hline Less than good & -0.0604 & 0.0144 & -0.0209 \\
\hline \multicolumn{4}{|l|}{ Household labour income } \\
\hline First quartile & - & - & - \\
\hline Second quartile & 0.1012 & -0.0238 & 0.0352 \\
\hline Third quartile & 0.0429 & -0.0103 & 0.0148 \\
\hline Last quartile & 0.0979 & -0.0231 & 0.034 \\
\hline \multicolumn{4}{|l|}{ Financial wealth } \\
\hline First quartile & - & - & - \\
\hline Second quartile & $0.2559 * * *$ & $-0.0628 * * *$ & $0.0885^{* * *}$ \\
\hline Third quartile & $0.2677 * * *$ & $-0.0654 * * *$ & $0.0927 * * *$ \\
\hline Last quartile & $0.1896^{*}$ & $-0.0477^{*}$ & $0.065^{*}$ \\
\hline \multicolumn{4}{|l|}{ Education } \\
\hline Primary & - & - & - \\
\hline Lower Secondary & $0.3408 * * *$ & $-0.0838 * * *$ & $0.1165^{* * *}$ \\
\hline Secondary & 0.1251 & -0.0333 & 0.0415 \\
\hline Bachelor or higher degree & 0.1183 & -0.0285 & 0.0409 \\
\hline \multicolumn{4}{|l|}{ Literacy 1 (real interest rate) } \\
\hline Incorrect answer & - & - & - \\
\hline Correct answer & 0.1183 & -0.0285 & 0.0409 \\
\hline
\end{tabular}


Table 5 (continued)

\begin{tabular}{|c|c|c|c|}
\hline & $\begin{array}{c}\text { Parameter } \\
\text { estimates }\end{array}$ & $\begin{array}{l}\text { Marginal effects on the } \\
\text { probability of rejecting the } \\
\text { annuity even at the lowest } \\
\text { lump sum }\end{array}$ & $\begin{array}{l}\text { Marginal effects on the } \\
\text { probability of choosing the } \\
\text { annuity even at the highest } \\
\text { lump sum }\end{array}$ \\
\hline \multicolumn{4}{|c|}{ Literacy 2 (risk diversification) } \\
\hline Incorrect answer & - & - & - \\
\hline Correct answer & $-0.178 * * *$ & $0.0414 * * *$ & $-0.0617 * * *$ \\
\hline \multicolumn{4}{|c|}{ Literacy 3 (private pensions) } \\
\hline No correct answer & - & - & 一 \\
\hline 1 correct answer & 0.044 & -0.0105 & 0.0153 \\
\hline 2 correct answers & -0.0036 & 0.0009 & -0.0012 \\
\hline 3 correct answers & 0.1361 & -0.0312 & 0.0476 \\
\hline 4 correct answers & 0.2101 & -0.0467 & 0.0739 \\
\hline \multicolumn{4}{|l|}{ Stock market participation } \\
\hline No & - & - & - \\
\hline Yes & $-0.2505^{* *}$ & $0.0635^{* *}$ & $-0.0845^{* *}$ \\
\hline \multicolumn{4}{|l|}{ Discount rate } \\
\hline Very low & - & - & - \\
\hline Medium & $-0.3533 * * *$ & $0.0752 * * *$ & $-0.1324 * * *$ \\
\hline High & $-0.6591 * * *$ & $0.1621 * * *$ & $-0.2363^{* * *}$ \\
\hline Very high & $-0.9328 * * *$ & $0.2546^{* * *}$ & $-0.3147 * * *$ \\
\hline Number of observations & 2,457 & 2,457 & 2,457 \\
\hline Pseudo $R^{2}$ & 0.070 & 0.070 & 0.070 \\
\hline
\end{tabular}

Note: Significance levels: 1 per cent $(* * *) ; 5$ per cent $(* *) ; 10$ per cent $(*)$.

small. However, it is expected to rise substantially in the future, since at present about 24 per cent of the workforce in the private sector is enrolled in complementary pension plans which, under Italian law, require the conversion of at least half of the accumulated capital into an annuity at retirement (data about pension plan enrolment are provided by COVIP, the Italian pension regulator). ${ }^{52}$ The main obstacle to a faster development of the annuity market, according to many, is the high price currently charged by insurance companies for annuity products. In particular, Guazzarotti and Tommasino ${ }^{53}$ estimate that in the Italian market the money's worth ratio (i.e. the ratio between the net present value of the streams of payments expected from an annuity contract and the price of the contract) is on average equal to 77 per cent, a value which is significantly lower than in most advanced countries. This would imply that a $€ 500$ annuity (such as the one proposed to our respondents) would cost,

52 Contributions to the plans are not compulsory; however, a reform implemented in 2007 has significantly strengthened the incentives to join employer-sponsored pension plans (in particular, an automatic enrolment provision has been added). Cesari et al. (2008) provide a description of the institutional details of the Italian fully funded pension pillar.

${ }^{53}$ Guazzarotti and Tommasino, op. cit. 
Table 6 Demand for annuities: Binomial models (heads of household aged 65 or younger)

\begin{tabular}{|c|c|c|c|}
\hline & Lump sum $=60,000$ & Lump sum $=80,000$ & Lump sum $=100,000$ \\
\hline \multicolumn{4}{|l|}{$\operatorname{Sex}$} \\
\hline Female & - & - & - \\
\hline Male & -0.0007 & -0.0257 & -0.031 \\
\hline \multicolumn{4}{|l|}{ Age (years) } \\
\hline$<=30$ & - & - & - \\
\hline $31-40$ & -0.0178 & -0.0131 & 0.0162 \\
\hline $41-50$ & 0.0266 & 0.0416 & $0.0801^{*}$ \\
\hline $51-65$ & $0.0631^{*}$ & $0.0752 *$ & $0.1656^{* * *}$ \\
\hline \multicolumn{4}{|l|}{ Marital status } \\
\hline Not married & - & - & - \\
\hline Married & -0.0029 & -0.0325 & -0.019 \\
\hline \multicolumn{4}{|l|}{ Children } \\
\hline No children & - & - & - \\
\hline One or more children & -0.0139 & 0.0034 & 0.0086 \\
\hline \multicolumn{4}{|l|}{ Risk aversion } \\
\hline Low & - & - & - \\
\hline Medium & 0.0483 & 0.0521 & 0.0447 \\
\hline High & 0.0548 & 0.0472 & -0.0121 \\
\hline \multicolumn{4}{|l|}{ Health } \\
\hline Very good or good & - & - & - \\
\hline Less than good & -0.0278 & $-0.0492^{*}$ & -0.0384 \\
\hline \multicolumn{4}{|l|}{ Household labour income } \\
\hline First quartile & - & - & - \\
\hline Second quartile & $0.0622 * * *$ & $0.0762^{* * *}$ & 0.0393 \\
\hline Third quartile & 0.0256 & $0.0688^{* *}$ & $0.055^{*}$ \\
\hline Last quartile & 0.0279 & $0.0722^{* *}$ & $0.0949 * * *$ \\
\hline \multicolumn{4}{|l|}{ Financial wealth } \\
\hline First quartile & - & - & - \\
\hline Second quartile & $0.0903 * * *$ & $0.0957 * * *$ & $0.0771 * * *$ \\
\hline Third quartile & $0.0921 * * *$ & $0.1072 * * *$ & $0.0717 * *$ \\
\hline Last quartile & $0.0914 * * *$ & $0.1223^{* * *}$ & $0.0581^{*}$ \\
\hline \multicolumn{4}{|l|}{ Education } \\
\hline Primary & - & - & - \\
\hline Lower Secondary & 0.0034 & -0.0072 & 0.0345 \\
\hline Secondary & 0.024 & 0.0469 & $0.1344 * * *$ \\
\hline Bachelor or higher degree & 0.0102 & $0.0666^{*}$ & $0.1913^{* * *}$ \\
\hline \multicolumn{4}{|l|}{ Literacy 1 (real interest rate) } \\
\hline Incorrect answer & - & - & - \\
\hline Correct answer & 0.0126 & 0.0391 & $0.0837 * * *$ \\
\hline
\end{tabular}


Table 6 (continued)

Lump sum $=60,000 \quad$ Lump sum $=80,000 \quad$ Lump sum $=100,000$

\section{Literacy 2 (risk diversification) Incorrect answer Correct answer}

Literacy 3 (private pensions)

No correct answer

1 correct answer

2 correct answers

3 correct answers

4 correct answers

Stockmarket participation

No

Yes

Number of observations

Pseudo $R^{2}$

$$
-0.0228
$$

$-0.044 * *$

$-0.1233^{* * *}$

$-\overline{0}$
$0.0517 * *$
$0.0492 * *$
$0.0622 * * *$
$0.0991 * * *$

$0.063 * *$

$0.0667 * *$

$0.0651^{* *}$

$0.0798^{*}$

$0.0574 * *$

$-0.0027$

$0.0611 * *$

$0.0934^{*}$

Note: Significance levels: 1 per cent $(* * *) ; 5$ per cent $(* *), 10$ per cent $(*)$.

in the real world, about $€ 105,000$. In turn this would imply, given our estimated annuity demand schedule, and given the characteristics of our sample, a probability of opting for an annuity equal to 26 per cent.

Of course, we do not claim that these back-of-the-envelope calculations count as a validation of our estimates. Our point is instead that: (1) notwithstanding their obvious limitations, survey answers to hypothetical choices have some potential in explaining real-world behaviour; and, (2) when interpreting actual choices, it is crucial to distinguish the role of annuity demand from the role of supply-side characteristics.

\section{Conclusions and policy implications}

In this paper, we measured the strength of annuity demand at retirement using a sample representative of the Italian heads of household, adopting an empirical strategy able to control for differences in annuitised wealth, prices and other product characteristics.

On average, we find that there is a strong demand for annuity products, at least compared with the demand we observe today, at current market prices. ${ }^{54}$

\footnotetext{
${ }^{54}$ At the moment, the Italian annuity market is very small (Guazzarotti and Tommasino, op. cit.). The amount of annuity purchases, either by individuals or via pension funds, is small. While exact figures concerning single-premium immediate annuities (i.e. the plain vanilla annuity product that we study in the present paper) are not available, the number of deferred annuities (which bundle together an investment product and an option to convert the final wealth into an annuity) which are in the pay-out phase was only about 15,000 in 2006. Even if this number is increasing (almost a third of outstanding contracts were signed in 2005), in the 2003-2005 period, out of 1,940,000 deferred annuities contracts which became due, only 11,000 investors preferred the annuity to the lump sum.
} 
However, our empirical analysis highlights that this statement requires important qualifications. ${ }^{55}$ In fact, we have also shown that for poorer, less educated individuals, annuity demand is significantly lower than average, and the price elasticity of annuity demand is significantly higher. These individuals are also those who, without an annuity, are more likely to end up with insufficient resources if they happen to live longer than they expected. This in turn would increase old-age poverty and/or welfare spending. It is quite likely that the annuity demand of these vulnerable subgroups is sub-optimal, either because they do not understand the importance of insuring against longevity risk, or because they are prevented from taking advantage of longevity insurance due to stringent liquidity constraints. ${ }^{56}$ It therefore seems that a case can be made for public policies to help these groups to increase the annuitised fraction of their retirement wealth.

How can this be done? Policies that prevent annuity prices from increasing too much above their actuarially fair benchmark are the obvious first step. Indeed, there is by now ample evidence that annuity prices are quite high. ${ }^{57}$ To curb these prices, governments should foster competition among insurance companies and at the same time should help them manage the aggregate component of the longevity risk. For example, by promoting the timely release of accurate life tables or by providing adequate amounts of very-long-term bonds and longevity bonds. ${ }^{58}$ Public provision of annuities could also be efficiency-enhancing, as the State could sell annuities at a price nearer to the actuarially fair one (with respect to private insurance companies, it would be in a better position to manage aggregate longevity risk, and would probably have lower administrative and marketing costs). ${ }^{59}$ Increasing the reach of adequate financial education represents a second potentially fruitful policy. In particular, governments should promote not only programmes aimed at providing basic financial skills, but also specific programmes concerning pension-related topics, in order to raise awareness of retirement needs and longevity risk. As a policy of last resort, the minimum fraction of pension wealth that has to be annuitised at retirement could be mandatorily increased. This policy would probably improve the welfare of investors

${ }^{55}$ Another aspect that requires caution when extending our findings to other contexts is the possible existence of a status quo bias in favour of annuitisation. Indeed, Italian workers typically hold a large fraction of their wealth in an annuitised form. The existence of a bias in favour of the status quo ante is well documented (see e.g. Kahneman et al., 1991 as well as the references discussed in Kujal and Smith, 2008). For example, concerning the topic of our study, it appears that in the U.K. there is considerable resistance by personal pensioners to turn their lump funds into annuities, while occupational pensioners show virtually no desire to turn their pension incomes into lump sums (we are indebted to an anonymous referee for this remark).

${ }^{56}$ Under-annuitisation can be socially inefficient even if it is efficient from an individual point of view: for example it might be rational for the individual to cash out pension wealth and spend it immediately after retirement, thereafter relying on social assistance. However, by doing this individuals do not take into account that they are imposing a negative externality on taxpayers.

${ }^{57}$ See Mitchell et al. (1999) and Brown et al. (2001) for the U.S., Cannon and Tonks (2004, 2008) and Finkelstein and Poterba (2004) for the U.K., Guazzarotti and Tommasino (2008) for Italy. James and Song, op. cit. provide data for a large group of countries.

${ }^{58}$ Visco, op. cit.

${ }^{59}$ A similar arrangement has been adopted in Sweden, where the State has a monopoly over annuity provision. 
with behavioural biases. On the other hand, it also entails costs, as some individuals could turn out to be over-annuitised.

\section{Acknowledgements}

We are grateful to Daniele Franco, Giorgio Gobbi, Sandro Momigliano and two anonymous referees for encouragement and many helpful suggestions. We also thank seminar participants at the Netspar Pension workshop and at the ECB. The views expressed in the paper are our own, and do not necessarily reflect those of the Bank of Italy.

\section{References}

Agnew, J.R., Anderson, L.R., Gerlach, J.R. and Szykman, L.R. (2008) 'Who chooses annuities? An experimental investigation of the role of gender, framing, and defaults', American Economic Review 98(2): 418-422.

Ameriks, J., Caplin, A., Laufer, S. and Van Nieuwerburgh, S. (2011) 'The joy of giving or assisted living? Using strategic surveys to separate public care aversion from bequest motives', Journal of Finance 66(2): 519-561.

Banca d'Italia (2012) Economic Bulletin, n. 63 (January).

Brown, J.R. (2001) 'Private pensions, mortality risk, and the decision to annuitize', Journal of Public Economics 82(1): 29-62.

Brown, J.R. (2007) Rational and behavioural perspectives on the role of annuities in retirement planning, NBER working paper, no. 13537.

Brown, J.R. (2008) 'Financial education and annuities', OECD Journal: General Papers 1(3): 171-214.

Brown, J.R., Kling, J.R., Mullainathan, S. and Wrobel, M.V. (2008) 'Why don't people insure late-life consumption? A framing explanation of the under-annuitization puzzle', American Economic Review 98(2): 304-309.

Brown, J.R., Mitchell, O.S., Poterba, J.M. and Warshawsky, M.J. (2001) The Role of Annuity Markets in Financing Retirement, Cambridge, USA: MIT press.

Butler, M. and Teppa, F. (2007) 'The choice between an annuity and a lump sum: Results from Swiss pension funds', Journal of Public Economics 91(10): 1944-1966.

Butler, M., Peijnenburg, K. and Staubli, S. (2011) 'How much do means-tested benefits reduce the demand for annuities?', CESifo Working paper N. 3493, Munich, Germany.

Cannon, E. and Tonks, I. (2004) 'UK annuity rates, money's worth and pension replacement ratios, 1957-2002', The Geneva Papers on Risk And Insurance-Issues and Practice 29(3): 394-416.

Cannon, E. and Tonks, I. (2008) Annuity Markets, Oxford, UK: Oxford University Press.

Cesari, R., Grande, G. and Panetta, F. (2008) 'Supplementary pension schemes in Italy: Features, development and opportunities for workers', Giornale degli Economisti e Annali di Economia 67(1): 21-73.

Davidoff, T., Brown, J.R. and Diamond, P.A. (2005) 'Annuities and individual welfare', American Economic Review 95(5): 1573-1590.

Deaton, A. (1997) The Analysis of Household Surveys - A Microeconomic Approach to Development Policy, Washington, DC: The World Bank.

Diamond, P.A. and Orszag, P.R. (2004) Saving Social Security: A Balanced Approach, Washington, DC: The Brookings Institution.

European Commission (2011) 'The 2012 ageing report: Underlying assumptions and projection methodologies', European Economy, n. 4.

Faiella, I. and Gambacorta, R. (2007) The weighting process in the SHIW, Economic Working Papers No. 636, Bank of Italy, Rome.

Feldstein, M. and Siebert, H. (2002) Social Security Pension Reform in Europe, Chicago, IL: University of Chicago Press.

Finkelstein, A. and Poterba, J. (2004) 'Adverse selection in insurance markets: Policyholder evidence from the U.K. annuity market', Journal of Political Economy 112(1): 183-208. 
Franco, D. (2002) 'Italy: A never-ending pension reform', in M. Feldstein and H. Siebert (eds) Social Security Pension Reform in Europe, Chicago, IL: University of Chicago Press.

Franco, D. and Sartor, N. (2006) 'NDC in Italy: unsatisfactory present, uncertain future', in R. Holzmann and E. Palmer (eds) Pension Reform. Issues and Prospects for Non-Financial Defined Contribution (NDC) Schemes, Washington, DC: The World Bank.

Grossman, M. (2000) 'The human capital model', in A.J. Culyer and J.P. Newhouse (eds) Handbook of Health Economics, Vol. 1, Amsterdam: Elsevier.

Guazzarotti, G. and Tommasino, P. (2008) The annuity market in an evolving pension system: Lessons from Italy, CeRP Working Paper No. 77/08.

Horneff, W.J., Maurer, R.H., Mitchell, O.S. and Stamos, M.Z. (2009) 'Asset allocation and location over the life cycle with investment-linked survival-contingent payouts', Journal of Banking and Finance 33(9): 1688-1699.

Horneff, W.J., Maurer, R.H., Mitchell, O.S. and Stamos, M.Z. (2010) 'Variable payout annuities and dynamic portfolio choice in retirement', Journal of Pension Economics and Finance 9(2): 163-183.

Hurd, M. and Panis, C. (2006) 'The choice to cash out pension rights at job change or retirement', Journal of Public Economics 90(12): 2213-2227.

Inkmann, J., Lopes, P. and Michaelides, A. (2011) 'How deep is the annuity market participation puzzle?' Review of Financial Studies 24(1): 279-319.

James, E. and Song, X. (2002) Annuity markets around the world: Money's worth and risk intermediation, CeRP Working Paper, No. 16/01.

Johnson, R.W., Burman, L.E. and Kobes, D.I. (2004) Annuitized Wealth at Older Ages: Evidence From the Health and Retirement Study, Washington, DC: Urban Institute.

Kahneman, D., Knetsch, J.L. and Thaler, R.H. (1991) 'Anomalies: The endowment effect, loss aversion, and status quo bias', Journal of Economic Perspectives 5(1): 193-206.

Kotlikoff, L.J. and Spivak, A. (1981) 'The family as an incomplete annuity market', Journal of Political Economy 89(2): 372-379.

Kujal, P. and Smith, V.L. (2008) 'The endowment effect', in C.R. Plott and V.L. Smith (eds) Handbook of Experimental Economics Results, Ed. 1, Vol. 1, N. 7, Amsterdam: Elsevier.

Lusardi, A. (2008a) Household saving behavior: The role of financial literacy, information, and financial education programs, NBER Working Paper N. 13824.

Lusardi, A. (2008b) Financial literacy: an essential tool for informed consumer choice?, NBER Working Paper No. 14084.

Lusardi, A. and Mitchell, O.S. (2006) Financial literacy and planning: implications for retirement wellbeing, Pension Research Council Working Paper, Wharton School, University of Pennsylvania.

Mackenzie, G.A. (2006) Annuity Markets and Pension Reform, Washington, DC: International Monetary Fund Institute.

Mitchell, O.S., Brown, J.R., Poterba, J.M. and Warshawsky, M.J. (1999) 'New evidence on the money's worth of individual annuities', American Economic Review 89(5): 1299-1318.

Modigliani, F. (1986) 'Life cycle, individual thrift and the wealth of nations', American Economic Review 76(3): $297-313$.

Sheshinski, E. (2007) The Economic Theory of Annuities, Princeton, U.S.: Princeton University Press.

Turra, C.M. and Mitchell, O.S. (2005) The impact of health status and out-of-pocket medical expenditures on annuity valuation, University of Michigan, Retirement Research Center, Research Brief No. RB 2005-79.

Visco, I. (2007) 'Longevity risk and financial markets', in M. Balling, E. Gnan and F. Lierman (eds) Money, Finance and Demography: The Consequences of Ageing, SUERF Colloquium Volume 2006. Vienna: SUERF.

Visco, I. (2011) 'Fact-finding with regard to the decree law containing urgent measures for growth, equity and the consolidation of the public finances', Testimony of the Governor of the Bank of Italy.

Warner, J.T. and Pleeter, S. (2001) 'The personal discount rate: Evidence from military downsizing program', American Economic Review 91(1): 33-53.

Wooldridge, J.M. (2002) Econometric Analysis of Cross Section and Panel Data, Cambridge, MA: MIT Press.

Yaari, M. (1965) 'Uncertain lifetime, life insurance, and the theory of the consumer', Review of Economic Studies 32(2): 137-150. 


\section{About the Authors}

Giovanni Guazzarotti earned an MSc in Economics from Bocconi University and a $\mathrm{PhD}$ from Sapienza University, Rome. He is an economist in the Economic Research and International Relations Area of the Bank of Italy. His main research field is Financial Economics.

Giuseppe Cappelletti earned a BSc, an MSc and a PhD in Economics from Bocconi University. He is an economist in the Economic Research and International Relations Area of the Bank of Italy. His main research fields are Game Theory and Financial Economics.

Pietro Tommasino earned a BSc, an MSc and a PhD in Economics from Bocconi University. He is an economist in the Economic Research and International Relations Area of the Bank of Italy. His main research fields are Public Finance and Public Choice. 